\title{
Allelopathic Potentiality of Euphorbia hypericifolia L. on Germination and Seedling Development of Sympatric Crops and Weeds
}

\author{
L. M. Ndam ${ }^{1}$, A. M. Ngone ${ }^{1}$, R. N. Nkongho ${ }^{1}$ A. G. N. Fongod ${ }^{2}$, A. S. Tening ${ }^{1}$ and Y. Fujii ${ }^{3}$ \\ ${ }^{1}$ Agronomic and Applied Molecular Sciences, University of Buea, PO Box 63, Buea Cameroon \\ ${ }^{2}$ Biological Science, University of Yaounde 1, Yaounde 337, Cameroon \\ ${ }^{3}$ Department of International Environmental and Agricultural Sciences, Tokyo University of \\ Agriculture and Technology, Tokyo 183-8509, Japan. \\ ${ }^{*}$ Corresponding author email: ndam.lawrence@ubuea.cm \\ Received: 11 March 2021 / Revised: 09 April 2021 / Accepted: 12 April 2021 / Published: 18 April 2021
}

\begin{abstract}
Euphorbia bypericifolia, a non-native herbaceous weedy plant was found to often form disproportionately dense, virtually monospecific stands in the Mount Bambouto Caldera, Cameroon. This observation is within the purview of allelopathy and is attributed to the release of botanicals by non native plants that harm naïve native flora, creating significant problems for agriculture and the environment. We investigated if the invasiveness of E. hypericifolia could be explained by its allelopathic potential at varying concentrations on five indicator plants. The results showed that the leaf, root and stem aqueous extracts of the plant exhibited significant inhibitory effects on the germination, radicle and plumule lengths of Biden pilosa, Amaranthus spinosus, Lactuca sativa, Zea mays and Lycopersicon esculentum at $100 \%$ by 75.0, 69.4, 95.6, 28.0 and $97.2 \%$, respectively. The leaf extract was the most potent, while the stem extract was the least. The extract of E. hypericifolia was stimulatory (Lower concentrations) and inhibitory to the germination and growth of the test plants and its effect was concentration-dependent with the roots of target plants being more sensitive to the extracts than the plumule. L. esculentum was the most susceptible species to E. hypericifolia extracts while $Z$. mays was more tolerant than any of the tested plants. Results of total chlorophyll pigment accretion showed declining levels of chlorophyll detected in the leaves of tomato transplants cultivated in the augmented soils with rising dosage of the leaf residue of E. hypericifolia. B. pilosa planted on E. hypericifolia infested soil (EIS) showed very poor emergence recording only $7.5 \%$ after 6 weeks as compared to $83.0 \%$ in non E. hypericifolia infested soil (NIS). Qualitative phytochemical screening indicates E. bypericifolia is rich in secondary metabolites including alkaloids, glycosides, flavonoids, phenolics, tanins, Steriods and saponins. Acetone was the best extractant amongst the solvents used. This study has proven the allelopathic potential of E. bypericifolia and revealed some allelochemicals that may be exploited for the development of bioherbicides and plant growth promotion from natural products.
\end{abstract}

Keywords: Invasive plants, Euphorbia hypericifolia, Allelopathy

\section{Introduction}

Any terrestrial ecosystem has diverse species of plants amongst other members. One of the Key members among plant categories are the invasive alien species which when anthropogenically or naturally introduced outside their natural abort, transit from feeble into compelling competitive species that impair the native flora. Plant invasion is a global environmental problem attributed to non-native invasive plants that recruit reproductive offspring, and usually in extremely large numbers that eventually spread rapidly in the novel habitat [1]. Such invasive-alien-species-driven activities that also result in environmental degradation and

Copyright (C) 2021. The Author(s). Published by AIJR Publisher.

This is an open access article under Creative Commons Attribution-NonCommercial 4.0 International (CC BY-NC 4.0) license, which permits any non-commercial use, distribution, adaptation, and reproduction in any medium, as long as the original work is 
biodiversity loss have the potential to completely alter core structures and functions of recipient ecosystems [2] and [3]. However, in many cases, the effects of invasive alien plants on the environment, especially in terms of the direction and magnitude, and also factors that influence their invasion processes are often unknown [4]. The 'Novel Weapon Hypothesis' has been propounded as the mechanism behind the suppressive and dominant effects of invasive alien plants on other plants and the accompanying changes observed in core components of the environment [5]. This is manifested by exerting the allelopathic effect via the release of varied qualities and quantities of allelochemicals that alter levels of macro and micro nutrients immobilization and uptake, and biochemical processes involved in plant growth and development [6], [7], [8] and [9].

Plant Chemical Ecologist point to Allelopathy as a key influence to an organism`s ability to establish as invasive alien plant species in diverse ecosystems [8]. Allelopathy is an age-old concept and the term was first used by Molisch in 1937 to mean all biochemical interactions, stimulatory or inhibitory among plants including microorganisms [10]. In this age, the term denotes a biological process where plant interactions result in unleash of botanicals that are either deleterious or beneficial to one or the other's germination or growth, and recruitment of offspring [11] and [12]. Allelochemicals are differently liberated from roots, stems and leaves of plants by exudation, leaching and volatilization respectively, and residue decomposition [13] and [14]. Research already promulgates the adoption of the allelopathic phenomenon in weed control in efforts to diminish reliance on chemical herbicides that usually exude great harm to the environment [15] [16] and [17].

As awareness rises about the pitfalls of environmental pollution and desire enlarges for organic agriculture that produces food that is healthy enough for human consumption, need arises for finding ways to replace and thus reduce the reliance on synthetic chemicals for farming [18] and [19]. In the face of that score, allelopathy holds great propensity for how such demands can be met. Contemporary studies on allelopathy accentuate on identifying specific allelochemicals that are active, and then isolating and quantifying them [20] These isolates, once identified and characterised, may serve as templates for the development of new herbicides that are environmentally less injurious [21] and [22]. Recent developments in analytical technology have spread tentacles in many disciplines, including agriculture and allelopathy in particular, chiefly in the aspect of exposure to state-of-the-art instrumentation. These have notably strengthened procedures such as prospecting and allelochemicals identification, push mastery of allelopathic operations, and crucially expedite the employment of allelochemicals in agricultural weed smoothing [23].

Bioprospecting for allelopathic plants from the natural flora is one promising step in the identification of potent lead compounds for the production of bio-herbicides [24], [25] and [26]. Cameroon an epitome of foreign invasive plants introduced since the European and German colonisation periods (1900-1961), is a perfect setting for bioprospecting for allelopathic activity. According to Onana [27], Cameroon habours over 9,050 plant species with over 160 endemics. However, Cameroon's flora is largely incompletely known with new and endangered species still being described [28]. One of such poorly surveyed areas is the Mount Bambouto Caldera, Lebialem Division of the South West Region of Cameroon. The Mount Bambouto Caldera is located between latitudes $5^{\circ} 44^{\prime}$ and $5^{\circ} 36^{\prime} \mathrm{N}$ and longitudes $9^{\circ} 55^{\prime}$ and $10^{\circ} 07^{\prime} \mathrm{E}$, and on an altitudinal range of $200 \mathrm{~m}$ at the bottom to $2700 \mathrm{~m}$ at the top of the Caldera [29]. It has an equatorial climate with an annual rainfall of 2,000-3,000 $\mathrm{mm} \mathrm{[30]} \mathrm{and} \mathrm{[29].} \mathrm{This} \mathrm{area} \mathrm{is} \mathrm{highly} \mathrm{isolated} \mathrm{due} \mathrm{to} \mathrm{the} \mathrm{lack} \mathrm{of} \mathrm{access} \mathrm{road}$ and basic utilities, preventing perturbation of its environment, and making it a hotspot of biodiversity. The Caldera has intact vegetation that is devoid of a comprehensive botanic survey even though it encompasses flora that is ecologically significant to science and livelihood enhancement [31]. Harvey et al. (31) in a rapid survey of the lower part of the Mount Bambouto Caldera reported six species (endemic to the Caldera) new to science with one of such being Argocoffeopsis fosimondi (Rubiaceae). These facts and the booming touristic industry in the area that is a channel for introduction of invasive alien species spurred the biodiversity survey of this area.

During a MINAGRI/COCADEF joint biodiversity survey of the Bamboutos Caldera in 2020, we came across a plant that dominated other species wherever it occurred, though a herb [32]. It was observed that 
this herbaceous weedy plant often formed disproportionately dense, virtually monospecific stands (Fig.1), wherein any other species' natural monospecific stands are infrequent.

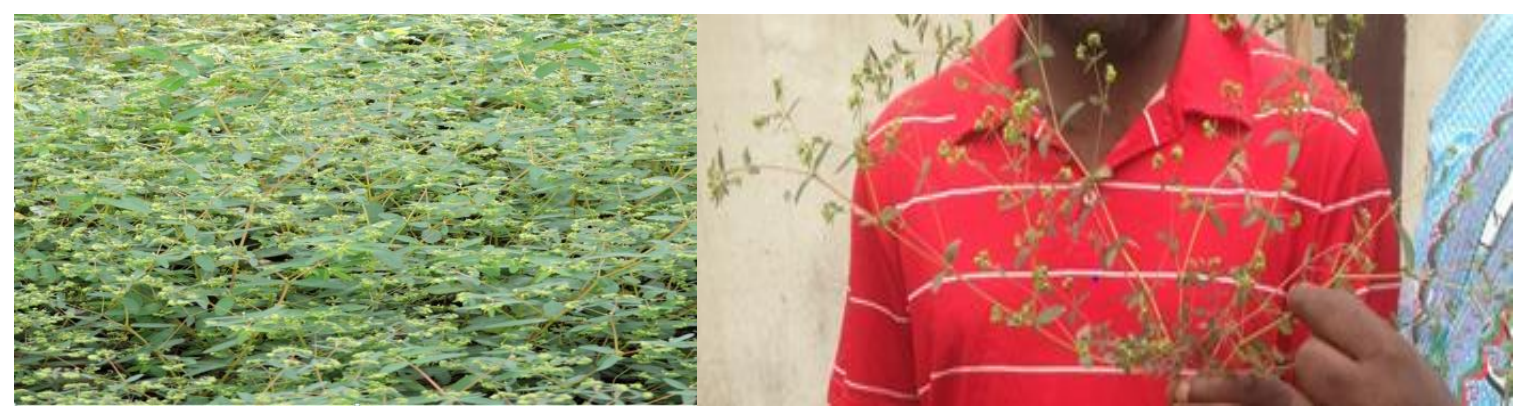

Figure1: First observation of dispropotionately high density monospecific stands of Eurphorbia hypericifolia in the Mount Bambouto Caldera, Cameroon (courtesy, Ndam Lawrence Photo Gallery, 2020)

Further, the areas directly beneath or within the vicinity of the species inhibit the germination, growth, survival, and reproduction of native plants. The competitive nature of the plant did not explain the mechanism of its perpetuation and suppression of other plants. This plant was later identified as Euphorbia bypericifolia L, a Euphorbiaceae of the order Mapighiales [33]. Voucher specimens were deposited at the Limbe Botanic Garden Herberium (SCA: 1689). E. hypericifolia, an annual native to Central America, is now reported in Cameroon where it is a nuisance in subsistent farming systems. Hitherto, it has been reported as an invasive plant in many parts of the Pacific Islands where they occur, and particularly rated 'high risk' weed in Hawaii [34], [35]. Other settings of E. hypericifolia are in Italy, Singapore, and Taiwan, even though their activities as invasive weed species have not been systematically recorded [35]. Already, in some countries, it is recognized as a weed in sugar cane, tomato, soybean, cotton, lettuce, and maize farming, even as its threats to native flora is being examined in others countries [36]. These facts served as pointers within the purview of the allelopathic potential of E. hypericifolia. There are no allelopathetic studies on E. bypericifolia. To evaluate the potential risk of the E. bypericifolia interaction with neighbouring plants, seeds of lactuca sativa, Amaranthus spinosus, Bidens pilosa, Lycopersicon esculentum and Zea mays were exposed to different concentrations of the aqueous extract of the plant $(0 \%, 25 \%, 50 \%, 75 \%$ and 100$)$, using the percentage germinated seeds and morphological changes in the root and shoot as toxicity criterion. In addition, phytotoxic effect of soil-incorporated dried leaf residue at varying concentrations on tomato leaf chlorophyll content in the greenhouse and phytochemical screening of. E. bypericifolia were elucidated.

\section{Materials and Methods}

\subsection{Source of Test or acceptor Plants}

Five acceptor species were used to examine the allelopathic effects of E. bypericifolia on seed germination and seedling development. Seeds of lettuce (Lactuca sativa L.), maize (Zea mays L.) and tomato (Lycopersicon esculentum Mill.) were purchased from AgroTec (Technisem, Longue -Jumelles, France) representative seed distribution stores in Buea, Cameroon. Amaranthus spinosus (Spiny amaranth) and Bidens pilosa (black jack), which are ubiquitous in the wild and dominant in crop fields especially maize farms in South western Cameroon, were collected from the plants in maize farms and the wild in Buea at flower head and seed maturity. Seeds dislodged from the seed head were winnowed and stored in seed bags at room temperature. Mr Ndive Elias, field Taxonomist at the University of Buea, authenticated the identity of all the acceptor plants. Preliminary germination tests using the blotter method (method similar to control with distilled water in 2.3) were performed on the seed lot of acceptor species to ascertain the viability (Fig.2). Seeds were first surface- sterilised for two minutes in $90 \%$ ethanol and then for five minutes in $2.0 \%$ sodium hypochloride $(\mathrm{NaOCl})$, before rigorous sterile distilled water rinsing for use in each of the experiments [37]. 


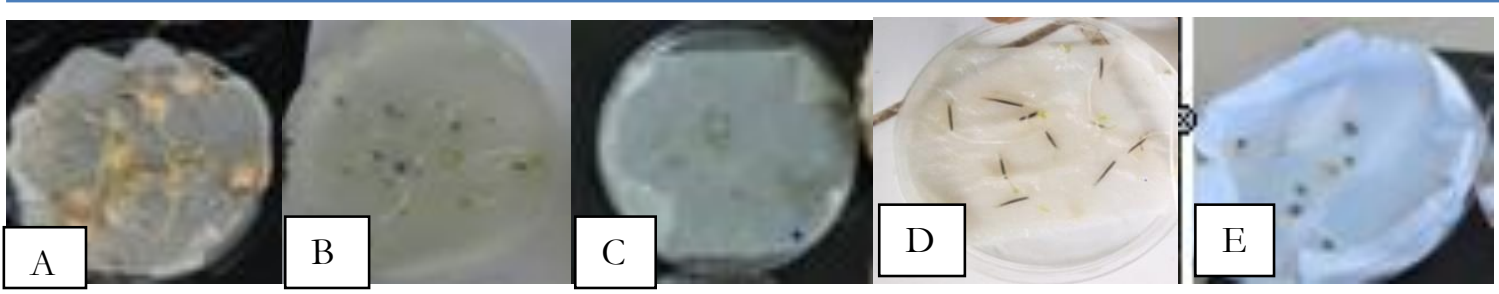

Figure 2: Pregermination trial of recipient species using aqueous blotter assay in the mount Bambouto Caldera, Cameroon A) Maize; B) Lettuce; C) Spiny Amaranth; D) Black Jack; E) Tomato

\subsection{Donor Plant Material and Preparation of test extracts}

E. bypericifolia (donor plant) was collected from the Afala hill in the mount Bambouto Caldera, Lebialem Division of Cameroon. The identity of the plant was authenticated by Botanists at the Limbe Botanic Gardens, Cameroon (SCA: 1689). The plants were separated into roots, stems and leaves, washed using tap water and air-dried under shade for three weeks. The dried plant materials were ground into powder using a grinding mill attached to a $2 \mathrm{~mm}$ sieve. The root, stem and leaf aqueous extracts of E. hypericifolia were prepared by soaking $200 \mathrm{~g}$ each of the powdered samples in $2 \mathrm{~L}$ of distilled water at room temperature and shaken on an orbital shaker (SOI Stuart Scientific Stone, U. K) for 24 h [38]. Each extract was then filtered through a Whatman No.1 (Tokyo Ltd, Japan) filter paper. The filtrate of each plant part was concentrated with a rotary evaporator (BUCHI Rotavapor R-200, Switzerland) and each dry matter weighed to get the yield. The dry matter yields for each part were stored at $4^{\circ} \mathrm{C}$ in glass bottles that were tightly sealed until time for use.

To constitute the aqueous infusion stock solution for each filtrate, $50 \mathrm{~g}$ of the filtrate of roots, stems and leaves of E. bypericifolia was put in a beaker containing $500 \mathrm{~mL}$ of distilled water and stirred [39]. The stock solution of each plant part was diluted in distilled water to obtain $100 \mathrm{~mL}$ of the working solutions $(25 \%$, $50 \%, 75 \%, 100 \%)$.

\subsection{Application of treatments, data collection and analysis}

The aqueous extracts of E. hypericifolia were used to assess inhibition of germination of lettuce, spiny amaranth, blackjack, tomato and maize. The treatments consisted of a factorial combination of four extract concentrations $(25 \%, 50 \%, 75 \%, 100 \%)$ and distilled water as control with three E. hypericifolia parts (Leaf, Stem and Roots), giving a total of fifteen treatments. For each of the five plant species, five $9 \mathrm{~cm}$ diameter Petridishes were each lined with two layers of Whatman No.1 filter paper per treatment. The filter paper in each Petridish was moistened with $8 \mathrm{~mL}$ of each of the 15 test extracts, replicated four times, giving a total of 60 petridishes per test species. 10 seeds of each species were plated in each of the 60 Petridishes and incubated in a Pro-grow incubator for 7 days. The cumulative germination was recorded daily. During the 7 days period of observation, germination for each seed was recorded once its radicle protruded to $\geq 1 \mathrm{~mm}$ in length [40]. The percentage seed germination was calculated as:

$$
\% \text { Germination }=\left[\frac{\text { Cumulative No. of Seed germinated }}{\text { No. of Seed planted }}\right] * 100 \ldots \ldots \ldots[1]
$$

After the 7-day duration of the experiment, elongations, each, of the radicle and plumule were determined via separate measurements of the corresponding lengths for 12 randomly selected samples from each treatment, by tracing with an inelastic string and reading the length off a meter rule. The percentage inhibition of the radicle and plumule lengths of - extract-treated seedlings was quantified in comparison to seedlings in the control group based on methods described by Piyatida et al. [41] as:

$$
\% \text { Inhibition }=1-\left[\frac{\text { Treatment }}{\text { Control }}\right] * 100
$$




\subsection{Allelopathic effect of dried leaf residue of $E$. hypericifolia on tomato leaf chlorophyll content}

Based on the observation that the leaf aqueous extract had the highest inhibitory effect on seed germination and seedling development, further confirmation of allelopathy was done by assessing the effect of incorporating dried leaf residue in a potting mix to determine tomato leaf chlorophyll content. Dried ground leaf tissue of E. hypericifolia at varying concentrations $(0,50,75,100, \mathrm{~g} / \mathrm{kg})$ were mixed with sterilized local sandy-loam soil in 5L plastic pots and used to assess the allelopathic effects of leaf tissue dosageresponse on tomato Chlorophyll leaf content. Pots were supplemented with decomposed poultry manure in a Manure- top soil ratio of 1:20. Each treatment was replicated 8 times giving a total of 32 experimental units (pots). The treatments were laid out in a completely randomised design in the greenhouse at $25^{\circ} \mathrm{C}$ for four weeks and the experiment was repeated twice. Four (4) week-old tomato seedlings (Cobra 26) were transplanted to the pots (one per pot). The soil was watered to field capacity and plants were given routine maintenance as desired. For the chlorophyll content, measurements were taken from three mature leaves of each plant at 1, 2, 3, and 4 weeks after transplanting. Three replicate samples of freshly harvested green leaf tissues of tomato $(100 \mathrm{mg})$ were homogenised by immersing in $25 \mathrm{~mL}$ of $80 \%$ acetone in a graduated tube and kept in a refrigerator at $4^{\circ} \mathrm{C}$ for $24 \mathrm{~h}$. The content of the tube was centrifuged at $2500 \mathrm{rpm}$ for 5 minutes to accelerate the pigments extraction. The extract liquid was decanted to remove leaf pieces and the supernatant transferred to another graduated tube. The leaf samples were rinsed repeatedly with a little volume of $80 \%$ acetone until they were completely free from green colour. Thus, the final volume of acetone was made up to $25 \mathrm{~mL}$ and the intensity of the green colour (absorbance (A) of chlorophyll content) of the supernatant was read at 663 and $645 \mathrm{~nm}$ against the solvent (acetone) blank in a Beckman spectrophotometer (Beckman UV-VIS 35, USA). The total chlorophyll content was estimated using the formula according to Arnon [42].

$$
\text { Total Chlorophyll }=20.2\left(A_{645}\right)+8.02\left(A_{663}\right) \ldots \ldots \ldots . .[3]
$$

Where $\mathrm{A}$ is the absorbance wavelength, $\mathrm{A}_{645}=$ absorbance of chlorophyll $\mathrm{b}$ at $\lambda=645 \mathrm{~nm}$, and $\mathrm{A}_{663}=$ absorbance of chlorophyll a at $\lambda=663 \mathrm{~nm}$

\subsection{Allelopathic effect of $\boldsymbol{E}$. hypericifolia rhizophoric soil on seedling emergence of Bidens pilosa}

\subsubsection{Collection of Weed Seeds and Soil}

The experiment was carried out at the University of Buea. Seeds of Bidens pilosa (black jack) were collected from the wild in the previous season (2019) from farms around the University of Buea. Two plots were selected at Banga Bakundu, Meme division for soil collection, one which was heavily infested by $E$. bypericifolia and the other not containing any trace of E. hypericifolia. The plot was judged heavily infested as a result of this weed constituting more than $90 \%$ of the total identifiable weed species. Other weeds occurring in very few numbers and showing chlorotic and wilting symptoms included B. Pilosa, A. spinosus, Ageratum conyzoides and Imperata cylindrica. Non E. hypericifolia infested soil had no E. bypericifolia. All soils were collected within the $0-15 \mathrm{~cm}$ zone. The soil samples were air-dried for two weeks in a protected area under a shade to avoid contamination and sieved using a $2 \mathrm{~mm}$ sieve.

\subsubsection{Experimental setup, data collection and statistical analysis.}

Perforated pots of $30 \mathrm{~cm}$ diameter were filed each with $3 \mathrm{~kg}$ of either E. hypericifolia infested soil or non E. bypericifolia. Two pots each were allocated per soil type for the seeding of Bidens pilosa. The experimenter set-up was a completely randomised design with four replications. Seed viability test of the Bidens pilosa was carried out as previously described in the control experiment in 2.3 above. Twenty seeds of each of Bidens pilosa were sown in each of the treatments in a total of 16 pots for the entire experiment. Pots were irrigated 
every other day to facilitate germination. Data on percentage seedling emergence were collected weekly, starting from one week after planting (WAP).

\subsection{Qualitative phytochemical screening of E. hypericifolia}

$100 \mathrm{~g}$ of air-dried roots, stem and leaves of E. hypericifolia were powdered and extracted in $1000 \mathrm{~mL}$ each for 48 hours sequentially in hexane, dichloromethane, acetone and water in the increasing polarity of solvent. The mixtures were filtered using Whatman filter paper No. 1 and the filtrates concentrated using a rotary evaporator at $40^{\circ} \mathrm{C}, 45^{\circ} \mathrm{C}, 40^{\circ} \mathrm{C}$ and $100^{\circ} \mathrm{C}$ respectively. To eliminate residual solvents, extracts were dried out at room temperature $\left(23-25^{\circ} \mathrm{C}\right)$, after which they were each weighted and preserved at $4^{\circ} \mathrm{C}$ until needed for use. Aliquots obtained from each of the crude extracts were used to test for the presence of phytochemicals in the Chemistry Laboratory of the University of Buea, Cameroon, using standard methods [43].

\subsection{Statistical Analysis}

The data were pooled, log-transformed, and run through analysis of variance (ANOVA) statistics using the Statistical Package for the Social Sciences (SPSS ${ }^{\circledR}$ ) version 13.0 (SPSS ${ }^{\circledR}$ Inc., Illinois, USA). Treatment means (Data are means \pm S.D in indicated cases) were separated by Duncan`s Multiple Range Test with the threshold of statistically significant differences set at $\mathrm{P} \leq 0.05$.

\section{Results and Discussion}

\subsection{Allelopathic effects of $E$. hypericifolia on seed germination, radicle and plumule growth}

\subsubsection{Effect on germination}

Adding of aqueous extracts of E. hypericifolia Leaf, root and stem, to samples resulted in statistically significant $(\mathrm{P} \leq 0.05)$ reduction and at times stimulated germination of the five target seeds after 7 days of incubation. For each plant part, the percentage germination decreased progressively with an increase in concentration (Fig.3). The leaf was more potent than the root and the stem as it registered the lowest germination counts across the five test plants.

The extract at $100 \%$ inhibited the germination of black jack, spiny amaranth, lettuce, maize and tomato seeds by $75.0 \%, 69.4 \%, 95.6 \%, 28.0 \%$ and $97.2 \%$, respectively (Fig.3). However, maize seeds incubated with the extract at $75 \%$ also had statistically non significant percentage reduction with seeds exposed to $100 \%$ extract. Test seeds exposed to distilled water germinated faster and seedlings developed more rapidly than at infusion concentrations of $50 \%$ and higher. Seeds exposed to the $25 \%$ infusion concentration showed greater germination counts (stimulation (Hormesis)) than those of the higher concentration (Fig.3A and Fig.3B). The toxicity of the plant extracts was also dosage-dependent. Thus, an increase in the inhibitory activity of the extracts of the different plant parts on germination counts for the five test plants was observed with increasing concentrations of the extracts. The inhibitory strength of the different plant parts on seed germination of the five test plants was in the order leaf $>$ root $>$ stem. 

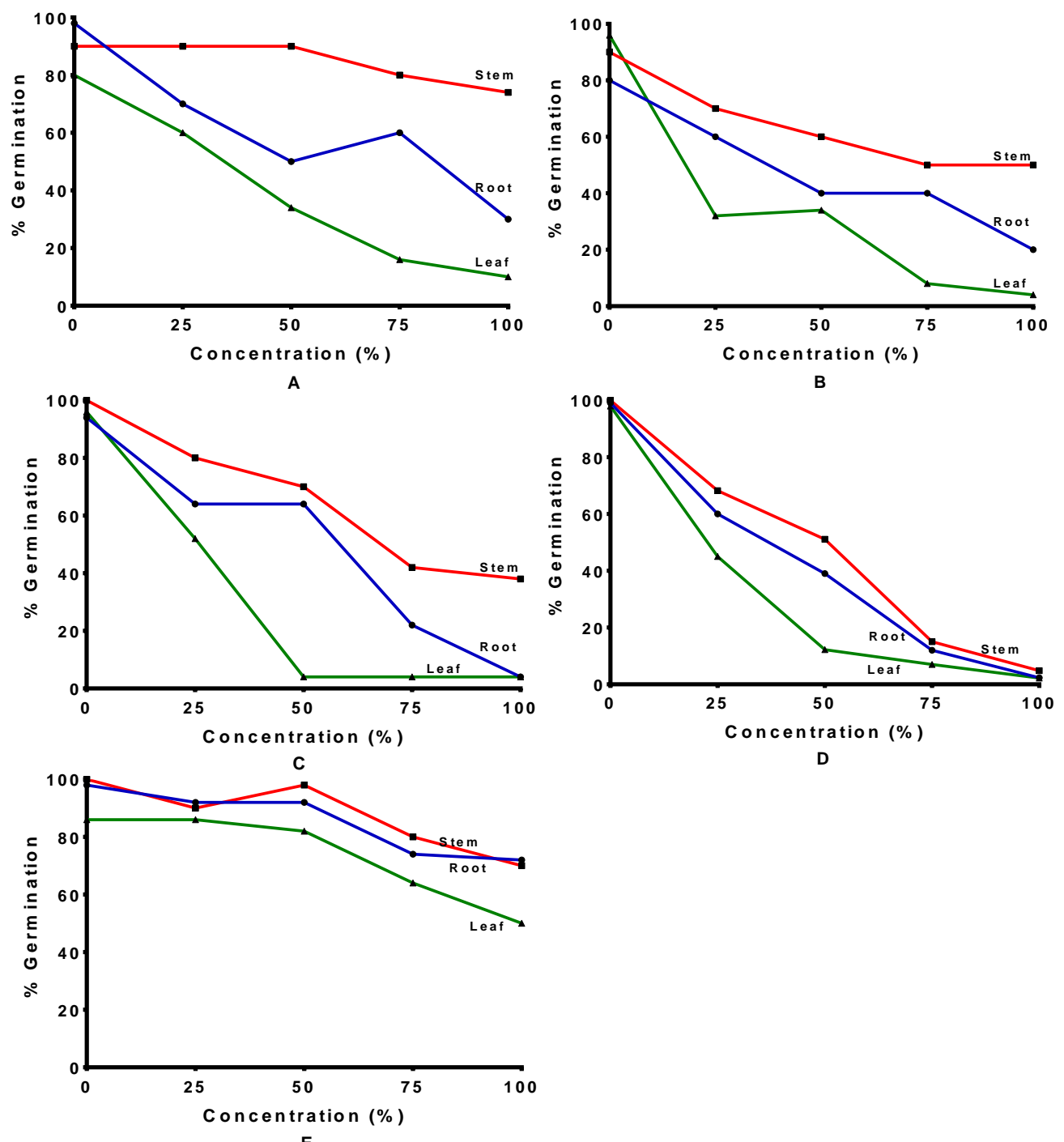

D

Figure 3: Effect of different concentrations of aqueous extracts of Leaf, Stem and the root of E. hypericifolia on seed germination. A) Spiny Amaranth; B) Blackjack; C) Lettuce; D) Tomato; E) Maize. (Data are means \pm S.D)

The observations of this study are in tandem with the inhibitory impact of the leaf, stem and root extracts of Brassica nigra [44], and pulses [45] which both altered crop germination and growth and dependent on concentrations of their aqueous extracts. Additionally, with the leaf extract, levels of water uptake needed to stimulate seed germination significantly decreased with increasing concentration [46], [47]. Nonetheless, for the corn seeds, the nature of their testa likely influenced how much water uptake would be necessary for reactivation of metabolism to support germination, and also resistance to the aqueous concentrate. Differences between the other target seeds and corn seeds could stem from the hygroscopic tissue of micropyle-hilium fissure which facilitates water uptake in the seeds of certain plants [48], but also could be due to variability in osmotic potential of the aqueous extracts of the leaf. Basically, the extent to which extracts influence seed germination is highly dependent on the level of seed coat permeability and size [49]. Smaller-sized seed are, therefore, more often reactive to the presence of allelochemicals as also supported by evidence from Teasdale's recent study [50]. Maize seeds were larger than the seeds of the remaining target plants thus tolerance of allelochemicals as aforementioned (Fig.4). 


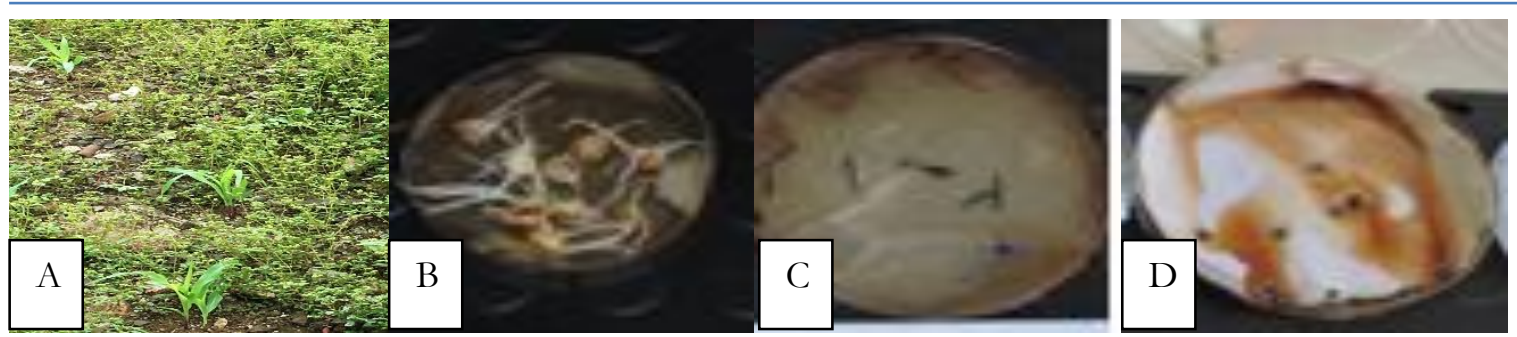

Figure 4: Allelopathic effect of E. hypericifolia on test plants in the mount Bambouto Caldera, Cameroon A) Maize grows luxuriantly along with E. hypericifolia in the field, indicative of tolerance of allelochemicals;

B) Stimulatory growth of maize seed in vitro under the influence of Euphorbia hypericifolia leaf extract; C) Moderately high inhibitory effect of E. hypericifolia leaf extract on the growth of Black jack; D) Strong inhibition of Tomato seed growth and development by E. hypericifolia leaf extract

In the control group where lower leaf extracts concentrations could have influence water uptake, germination was greater relative to seeds in the treated group. The importance of water uptake in seed germination has been attributed to its stimulation of certain metabolic and physiological processes that occur [46]. While the chain of biochemical events that initiate seed germination is still to be explained [51], [52]; evidence points toward a sequence of hydrolytic enzyme activity that follow increases in respiration, and then enlargement in the embryo after cell division; key processes which all could have been altered by the presence of allelochemicals from the aqueous leaf extracts [53]. In the face of species-based disparities in response to test extracts, allelochemical-influence on floristic composition becomes crucial to managing natural environments, but even more importantly for use as selective herbicides in agriculture [54]. The multiple chemical structures and compounds with numerous phytotoxic effects that compose allelopathic chemicals have been said to be responsible for alterations that occur in seed germination and plant growth via interferences with core biochemical and physiological processes [55]. Fujii et al. [39] reports that plant enzyme and/or hormonal activities can be altered by phytotoxins, thus resulting in enhanced amylase activity and further release of embryo reserves, and alterations in the permeability of seed membrane. This leads to excessive production of abscisic acid and inhibition of water uptake, such that prolongs oxidative stress and seed dormancy [56]. In this regard, relative disparities recorded in seed germination for the treatment versus the control categories could be explained by the presence and non-presence of allelopathic compounds. Findings by Hill et al. [57] support these conclusions with reference to the effects on different plant species at varied concentrations of hairy vetch and cowpea extracts. Observed plant-specific allelochemical sensitivities could also be observed in crop cultivars in this study. This would for instance explain why our study findings show Tomato to be more sensitive to test extracts than Maize. The observed higher potency of the leaf relative to the roots and the stem is in synergy with the finding of Kamal [58] who opined that the leaf is the most important source of allelochemicals and a major site for the photosynthetic pathway that accounts for the upshot of the synthetic pathways for secondary metabolite production. The dosage-dependent nature of allelopathic interactions observed in this study collaborates the works of [59], [60], [61] and [62], which attributed this to the high concentration of allelochemicals gradients as extract concentration increases. Elsewhere, different plant parts extracts of Alternanthera species have been shown to delay the germination of rice seeds. In particular, aqueous extracts from Alternanthera philoxeroides and $A$. sessilis species were shown to each impede rice seed germination by a minimum of 9 and $4 \%$, and a maximum of 100 and $49 \%$, respectively. Furthermore, with the leaf extracts of both species, the degree of seed germination inhibition increased with increasing concentration [63].

\subsubsection{Effects on radicle and plumule growth}

The effects of the root, stem and leaf aqueous extract of E. bypericifolia on radicle and plumule growth of blackjack, spiny amaranth, lettuce, maize, and tomato incubated with different concentrations of the plant extracts matched patterns recorded for inhibition in seed germination (Table 1 and 2). The reductions in 
Ndam et al., Int. Ann. Sci.; Vol. 10, Issue 1, pp: 134-150, 2021

radicle length of the test plant seedlings caused by the addition of the root extract at $100 \%$ ranged between 35.3 to $94.0 \%$ (Table 1). The extract at $75 \%$ also resulted in more than $30 \%$ inhibition on the studied growth parameter of blackjack, spiny amaranth, lettuce and tomato incubated with the treatment. However, apart from blackjack, the root extracts at $25 \%$ and $50 \%$ on the radicle length of tomato, lettuce, spiny amaranth, and maize, respectively, were significantly different from each other. Tomato exposed to $25 \%$ extract concentration experienced a stimulatory radical growth $(-11.1 \%)$ while lettuce and maize followed a similar pattern at $25 \%$ and $50 \%$, respectively. In addition to the brownish colouration of the necrotic radical tips, it was twisted, thinner and showed retarded growth (Fig. 5). On the contrary, application of the leaf extract at $100 \%$ reduced the radicle length of tomato, blackjack and lettuce by 99.8, 99.6 and 99.3\%, respectively (Table 1). Apart from the non-significant difference and decreases recorded in the length, incubation in $50 \%, 75 \%$, and $100 \%$ extracts resulted in tomato radicle tips with a more brownish appearance and thinner diameters compared to those that were incubated in the $25 \%$ concentrate. A similar trend was observed for spiny amaranth at the two lower treatment concentrations. The stem material of $E$. bypericifolia exhibited a weaker allelopathic effect than the leaves and roots of the plant (Table 1). The stems of E. hypericifolia did however have some allelopathic potential that increased with increasing concentration for all the test plants.

Table 1: Percentage inhibition of radicle length of crops and weeds as influenced by the aqueous extracts of the root, stem and leaves of E. hypericifolia $L$

\begin{tabular}{lcccc|ccccccccc}
\hline Test species & \multicolumn{4}{c}{ Roots } & \multicolumn{3}{c}{ Stems } & \multicolumn{1}{c}{ Leaves } \\
\hline & $\mathbf{2 5 \%}$ & $\mathbf{5 0 \%}$ & $\mathbf{7 5 \%}$ & $\mathbf{1 0 0 \%}$ & $\mathbf{2 5 \%}$ & $\mathbf{5 0 \%}$ & $\mathbf{7 5 \%}$ & $\mathbf{1 0 0 \%}$ & $\mathbf{2 5 \%}$ & $\mathbf{5 0 \%}$ & $\mathbf{7 5 \%}$ & $\mathbf{1 0 0 \%}$ \\
\hline Black jack & $28.6 \mathrm{a}$ & $30.0 \mathrm{a}$ & $47.5 \mathrm{~b}$ & $53.3 \mathrm{~b}$ & $10.3 \mathrm{a}$ & $15.1 \mathrm{~b}$ & $19.9 \mathrm{bc}$ & $24.7 \mathrm{c}$ & $40.0 \mathrm{a}$ & $53.8 \mathrm{~b}$ & $77.3 \mathrm{c}$ & $99.6 \mathrm{~d}$ \\
Spiny amaranth & $3.1 \mathrm{a}$ & $15.0 \mathrm{~b}$ & $45.0 \mathrm{c}$ & $65.0 \mathrm{~d}$ & $-20.6 \mathrm{a}$ & $12.2 \mathrm{~b}$ & $18.5 \mathrm{c}$ & $21.6 \mathrm{c}$ & $32.0 \mathrm{a}$ & $32.0 \mathrm{a}$ & $16.7 \mathrm{~b}$ & $48.3 \mathrm{c}$ & \\
Lettuce & $-11.1 \mathrm{a}$ & $-4.6 \mathrm{~b}$ & $30.8 \mathrm{c}$ & $60.3 \mathrm{~d}$ & $-16.6 \mathrm{a}$ & $-40.5 \mathrm{~b}$ & $22.8 \mathrm{c}$ & $32.2 \mathrm{~d}$ & $52.1 \mathrm{a}$ & $64.6 \mathrm{~b}$ & $81.1 \mathrm{c}$ & $99.3 \mathrm{~d}$ \\
Maize & $-44.8 \mathrm{a}$ & $-65.7 \mathrm{~b}$ & $0.0 \mathrm{c}$ & $35.3 \mathrm{~d}$ & $-45.6 \mathrm{a}$ & $-68.0 \mathrm{~b}$ & $-14.7 \mathrm{c}$ & $17.6 \mathrm{~d}$ & $-8.4 \mathrm{a}$ & $41.6 \mathrm{~b}$ & $53.1 \mathrm{c}$ & $66.3 \mathrm{~d}$ \\
Tomato & $-11.1 \mathrm{a}$ & $32.0 \mathrm{~b}$ & $60.0 \mathrm{c}$ & $94.0 \mathrm{~d}$ & $-27.6 \mathrm{a}$ & $44.9 \mathrm{~b}$ & $54.4 \mathrm{c}$ & $82.8 \mathrm{~d}$ & $57.4 \mathrm{a}$ & $90.0 \mathrm{~b}$ & $92.0 \mathrm{~b}$ & $99.8 \mathrm{~b}$ \\
\hline
\end{tabular}

For each plant part (roots, stems and leaves), means along a row with the same letters are not significantly different from each other at $\mathrm{P} \leq 0.05$

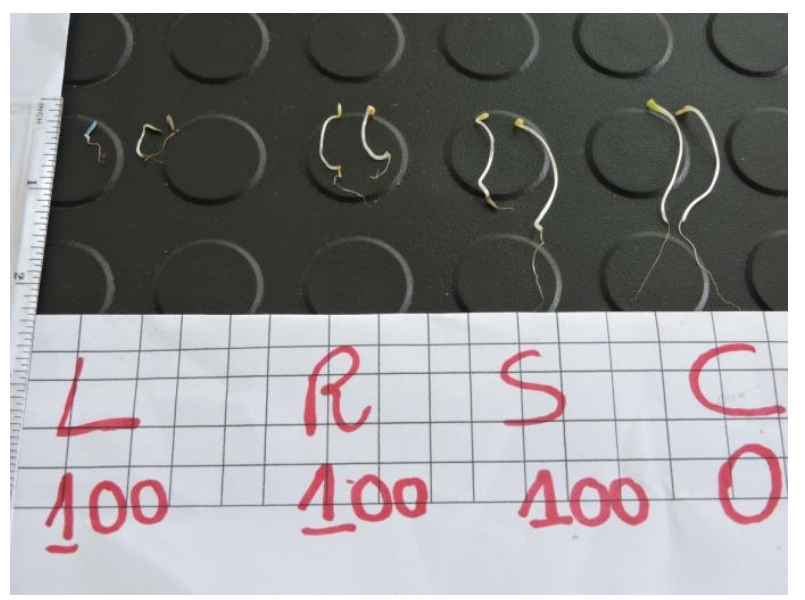

Figure 5: Allelopathic Effect of E. hypericifolia L on radicle and plumule of lettuce exposed to $100 \%$ Roots $(R)$, $\operatorname{Stem}(S)$ and Leaf $(L)$ extract concentrations and $(C)$ Control (distilled water)

Table 2 presents results of plumule growth inhibition, which relative to findings on radicle length inhibition, were less altered by the different extract concentrates. The root extract at $75 \%$ and $100 \%$ considerably reduced the plumule length of all the test plants except for maize that experienced a stimulation $(-69.5 \%$ and $-42.9 \%$ for the respective extract concentrations) and lettuce at $75 \%$ extract concentration $(-25.0 \%$ 
inhibition). The two lowest concentrations had minimal inhibition percentages on the plumule growth of all the test plants except for lettuce, maize and Spiny amaranth that reflected significant stimulatory growth of the plumule. Again, with the leaf extract, observed differences in the plumule growth of plants treated at varying concentrations were strongly significant (Table 2). While the extract at $100 \%$ had $93.1 \%, 90.8$ $\%$ and $78.7 \%$ inhibition on the plumule length of tomato, lettuce and blackjack respectively, that of spiny amaranth at the same extract concentration was reduced by $36.0 \%$. Generally, the effects of the leaf extract at $25 \%, 50 \%$ and $75 \%$ on the plumule growth of the five tested plants were significantly higher than those recorded for root extract at similar concentrations. However, maize experienced a stimulatory growth of $15.6 \%$ and $-48.8 \%$ at $25 \%$ and $50 \%$ leaf extract concentrations, respectively. The effect of the stem on the plumule at all concentrations followed a similar trend as for root and leaf but recorded the weakest allelopathic effect on the plumule growth. The extract concentration at $100 \%$ inhibited the plumule growth of tomato and lettuce by $81.6 \%$ and $30.2 \%$, respectively, while maize at the same concentration experienced $-45.9 \%$ plumule growth stimulation and a $-78.2 \%$ plumule growth stimulation at $25 \%$ extract concentration.

Of the plant parts investigated, stems had the least allelopathic potential but still showed inhibitory and stimulatory effects on test plants germination, radicle and plumule growth. Root infusions showed inhibition and moderate stimulatory effects of test plant germination, root and plumule growth, although it was lower than the effects from leaves which had the highest allelopathic potential of all plant parts tested. Tomato was the most sensitive plant to the allelopathic extract of E. hypericifolia, having an excruciating effect on its growth parameter while maize was the most tolerant species to the extracts of E. hypericifolia.

Table 2: Percentage inhibition of plumule growth of crops and weeds as influenced by the aqueous extracts of the roots, stems and leaves of E. hypericifolia

\begin{tabular}{lcccc|cccc|cccc}
\hline Test species & \multicolumn{9}{c}{ Roots } & \multicolumn{4}{c}{ Stems } & \multicolumn{3}{c}{ Leaves } \\
\hline & $\mathbf{2 5 \%}$ & $\mathbf{5 0 \%}$ & $\mathbf{7 5 \%}$ & $\mathbf{1 0 0 \%}$ & $\mathbf{2 5 \%}$ & $\mathbf{5 0 \%}$ & $\mathbf{7 5 \%}$ & $\mathbf{1 0 0 \%}$ & $\mathbf{2 5 \%}$ & $\mathbf{5 0 \%}$ & $\mathbf{7 5 \%}$ & $\mathbf{1 0 0 \%}$ \\
\hline Black jack & $8.3 \mathrm{a}$ & $27.1 \mathrm{~b}$ & $44.3 \mathrm{c}$ & $47.1 \mathrm{c}$ & $6.8 \mathrm{a}$ & $14.6 \mathrm{~b}$ & $18.5 \mathrm{bc}$ & $23.4 \mathrm{c}$ & $4.4 \mathrm{a}$ & $34.7 \mathrm{~b}$ & $54.7 \mathrm{c}$ & $78.7 \mathrm{~d}$ \\
Spiny amaranth & $-55.0 \mathrm{a}$ & $13.8 \mathrm{~b}$ & $23.1 \mathrm{c}$ & $38.5 \mathrm{~d}$ & $-57.3 \mathrm{a}$ & $10.8 \mathrm{~b}$ & $17.8 \mathrm{c}$ & $20.8 \mathrm{c}$ & $8.3 \mathrm{a}$ & $13.3 \mathrm{a}$ & $12.0 \mathrm{a}$ & $36.0 \mathrm{~b}$ \\
Lettuce & $-50.00 \mathrm{a}$ & $-25.00 \mathrm{~b}$ & $-25.00 \mathrm{~b}$ & $50.6 \mathrm{c}$ & $-67.7 \mathrm{a}$ & $-51.9 \mathrm{a}$ & $-44.5 \mathrm{~b}$ & $30.2 \mathrm{c}$ & $5.6 \mathrm{a}$ & $24.5 \mathrm{~b}$ & $75.1 \mathrm{c}$ & $90.8 \mathrm{~d}$ \\
Maize & $-69.3 \mathrm{a}$ & $-100.0 \mathrm{~b}$ & $-69.5 \mathrm{a}$ & $-42.9 \mathrm{c}$ & $-78.2 \mathrm{a}$ & $-75.9 \mathrm{a}$ & $-82.4 \mathrm{ab}$ & $-45.9 \mathrm{c}$ & $-15.6 \mathrm{a}$ & $-48.8 \mathrm{~b}$ & $51.2 \mathrm{c}$ & $58.8 \mathrm{c}$ \\
Tomato & $-28.0 \mathrm{a}$ & $28.1 \mathrm{~b}$ & $59.3 \mathrm{c}$ & $85.2 \mathrm{~d}$ & $-28.7 \mathrm{a}$ & $20.7 \mathrm{~b}$ & $51.7 \mathrm{c}$ & $81.6 \mathrm{~d}$ & $55.2 \mathrm{a}$ & $80.6 \mathrm{~b}$ & $85.6 \mathrm{bc}$ & $93.1 \mathrm{c}$ \\
\hline
\end{tabular}

For each plant part (roots, stems and leaves), means along a row with the same letters are not significantly different from each other at $\mathrm{P} \leq 0.05$

Radicles were more sensitive to the test extract than the plumules. These findings are not unexpected as similar findings showing greater sensitivity of radicle compared to plumule lengths have been previously reported [64] [65]. Increased inhibitory effects for extracts with higher concentration could be related to additional effects of the extract constituents that act in synergy with the isolated compound to boost potency [66], [67]. This study's findings of enhanced development of the fibrous root system of corn when treated with the lowest extract concentrates (i.e., $25 \%$ ) is backed by previous reports of variability in the stimulation and inhibition of crop germination and growth when treated with leachates of other plants [68] and [69]. Allelochemicals can alter levels of plasma membrane-based hydrogen adenosine triphosphatase that are needed to initiate the electrochemical proton gradient and therefore engineer the ions and metabolites absorption and efflux through membrane plasma [70]. Slow down or inhibition of hydrogen adenosine triphosphatase usually reduces water and mineral absorption through the roots, essentially 
Ndam et al., Int. Ann. Sci.; Vol. 10, Issue 1, pp: 134-150, 2021

impacting processes of photosynthesis, respiration, and protein synthesis that are core plant functionality, and thus resulting in growth impairment [71]. Our results correlate with the findings of Fujii et al. [39], who reported inhibition of seed germination and seedling growth of lettuce by aqueous extracts of Japanese medicinal plants. The observed drastic reductions of 99.8 and $99.6 \%$ on the radicle length relative to 93.1 $\%$ and $78.7 \%$ recorded for the plumule growth of tomato and blackjack treated with the leaf extract at 100 $\%$ respectively are in accordance with the findings of Maver et al [72].

\subsection{Allelopathic effect of dried leaf residue of E. hypericifolia on tomato leaf chlorophyll content}

As regards the total chlorophyll pigment accretion, figure 6 shows that observations within the first 14 days of experimentation, revealed declining levels of chlorophyll in the leaves of tomato transplants that were grown in the augmented soils with increasing concentration of E. hypericifolia leaf residue. However, the mean concentrations for chlorophyll pigment in the $7 \mathrm{~g}, 10 \mathrm{~g}$, and $17 \mathrm{~g}$ treatment do not significantly vary at 2 weeks post the transplanting. Also, not significantly different, were the mean concentrations of pigments in the $7 \mathrm{~g}$ and $10 \mathrm{~g}$ treatment and control groups, 3 and 4 weeks after transplants.

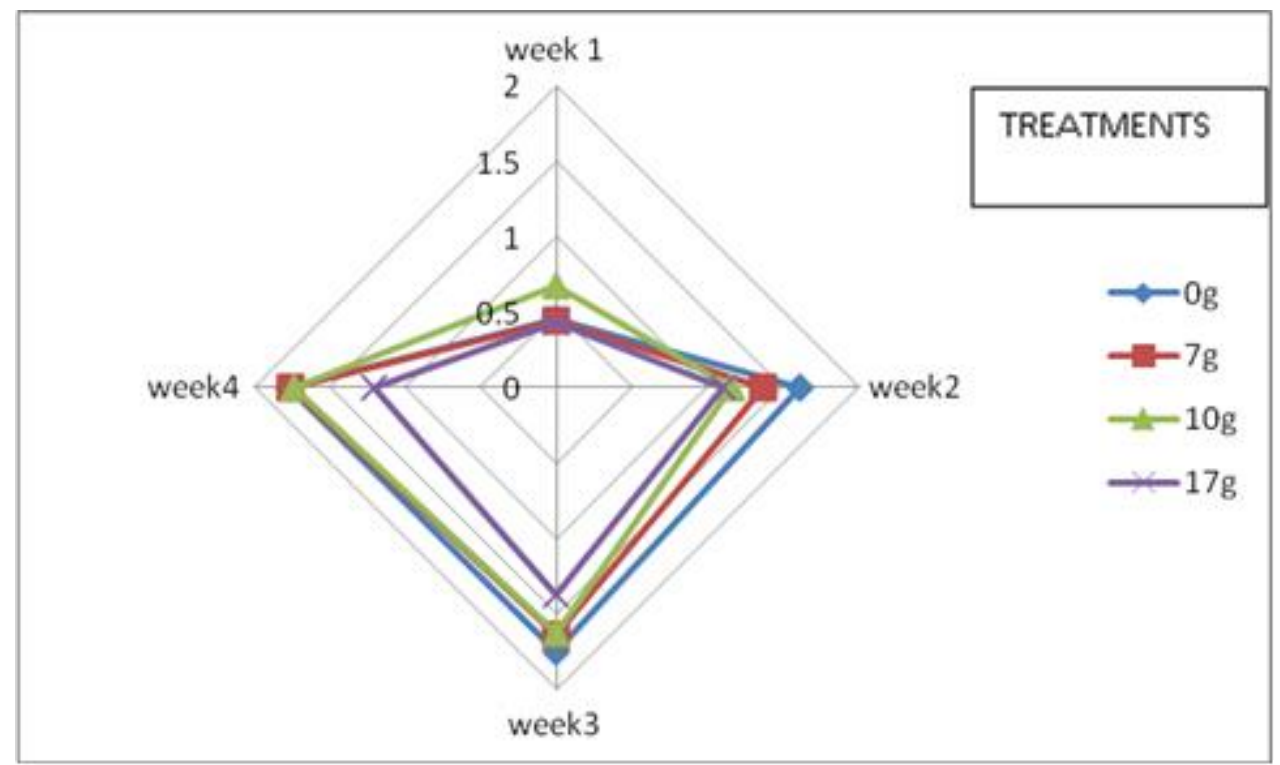

Figure 6: Allelopathic effects of the dried leaf residue of E. hypericifolia on tomato chlorophyll $\left(\mathrm{mg}^{-1}\right)$ content (Data are means $\pm S . D$ )

The data on chlorophyll pigment accretion revealed no reliable trends in the pigment build-up for leaves of tomato plants that were nourished through the augmented soils. According to Einhellig [73], the presence of allelochemicals is implicated in the substantial chlorophyll reductions that occur on test plants. While this study's findings are counter to this finding, statistically insignificant differences recorded in the chlorophyll pigment accretion for plants in the $7 \mathrm{~g}$ control and treatment groups relative to the others actually support the aforementioned report. Additionally, in line with findings from previous assessments [74][75], reductions in the chlorophyll content of plants treated with the $5.0 \%$ and $7.5 \%$ leaf extracts were statistically significant. Basically, this study reports evidence of reductions in photosynthesis that are the results of declines in chlorophyll content in both crop and weed plants [74]

\subsection{Seedling emergence of $B$. pilosa in soil infested with $E$. hypericifolia and uninfested soil}

The trend of the emergence of B. pilosa is shown in figure 7. B. pilosa planted on E. bypericifolia infested soil (EIS) showed very poor emergence recording only $7.5 \%$ after 6 weeks as compared to $83.0 \%$ in non E. bypericifolia infested soil (NIS). This difference may be attributed to the presence of allelochemicals in $E$. bypericifolia infested soil. B. pilosa has behaved similarly in reaction to leaf extract of Leucaena leucocephala [76]. 


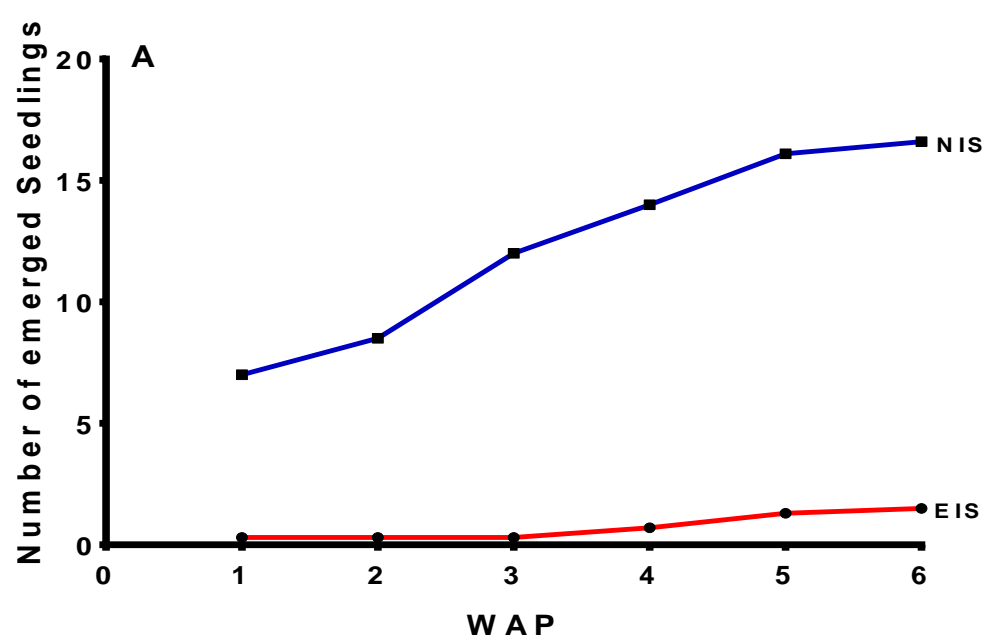

Figure 7: Seedling emergence of Bidens pilosa in soil infested with E. hypericifolia and uninfested soil (Data are means $\pm S . D$ )

The authors examined how much allelochemicals extracts in bioassays of L. leucocephala aerial parts would impact growth of Desmodium purpureum, B. pilosa, and A. hybridus species, and found that the sensitivity of $B$. pilosa was relatively greater [55]. Elsewhere, inhibitory growth effects of other plants on alternative test species have been observed [77]. As Otusanya et al. [78] report, T. diversifolia was shown to significantly inhibit germination and growth of Amaranthus crentus. In earlier investigations, micro-organisms activities during weed decomposition were posited to emit toxins that hampered core functions that enable plant growth [79]. Today, our study clearly uncovers differences with regard to significantly lower weed counts in E. hypericifolia infested soils compared to non-infested soils. E. bypericifolia infested soil is thus shown to contain allelochemicals that inhibit growth functions in other plants.

\subsection{Preliminary phytochemical screening of $E$. hypericifolia in solvents with differential polarities}

Results from analysis of bioactive compounds in E. hypericifolia extracts are presented in Table 3. Phytochemical screening revealed the presence of steroids, alkaloids, phenolics, cardiac glycosides, tannins, saponins, and flavonoids, although in varied quantities and classes in the plant extracts. The phytochemicals were more pronounced in the leaves than in the roots and stem and were more expressed in the acetone extract (higher degree of precipitation $(+++)$ followed by the water extract. Of all the phytochemicals, saponins was only detected in the acetone extract.

Table 3: Results of the phytochemical screening of the extracts of E. hypericifolia

\begin{tabular}{|c|c|c|c|c|c|c|c|c|c|c|c|c|}
\hline \multirow[t]{2}{*}{$\begin{array}{c}\text { Phytochemical } \\
\text { constituents }\end{array}$} & \multicolumn{3}{|c|}{$\begin{array}{c}\text { Hexane } \\
\text { extract }\end{array}$} & \multicolumn{3}{|c|}{$\begin{array}{c}\text { Dichloromethane } \\
\text { extract }\end{array}$} & \multicolumn{3}{|c|}{$\begin{array}{c}\text { Acetone } \\
\text { extract }\end{array}$} & \multicolumn{3}{|c|}{$\begin{array}{c}\text { Plant water } \\
\text { extract }\end{array}$} \\
\hline & $\mathrm{L}$ & $\bar{S}$ & $\mathrm{R}$ & $\mathrm{L}$ & $\bar{S}$ & $\mathrm{R}$ & $\mathrm{L}$ & $\mathrm{S}$ & $\mathrm{R}$ & $\bar{L}$ & $\mathrm{~S}$ & $\overline{\mathrm{R}}$ \\
\hline Alkaloids & + & + & + & + & + & + & + & + & - & + & + & + \\
\hline Steroids & + & + & + & ++ & + & + & + & + & - & - & - & - \\
\hline $\begin{array}{l}\text { Cardiac } \\
\text { glycosides }\end{array}$ & + & + & + & - & - & - & - & + & + & - & - & - \\
\hline Phenolics & + & - & - & - & - & - & +++ & + & + & +++ & - & - \\
\hline Tannins & + & - & - & - & - & - & ++ & + & + & ++ & ++ & + \\
\hline Flavonoids & - & - & - & + & ++ & + & +++ & + & + & + & + & + \\
\hline Saponins & - & - & - & - & - & - & + & + & - & - & - & - \\
\hline
\end{tabular}

Legend: L-Leaves, S-Stem, R-Roots, $(+++)=$ strongly present, $(++)=$ moderately present, $(+)=$ poorly present, $(-)=$ absent 
Leaf and root extracts of Hypochaeris radicata showed in vitro bioactivity on seeds of plants. Phytochemical screening of its leaf extracts revealed the presence of phenolics, terpenoids, alkaloids, and fatty acids [80]. Phenolic compounds as were predominantly present in the extracts could have principally or in synergy with other groups of compounds inhibited germination, growth, and development of seedlings in this study. This is the first reported findings on the phytochemical constituents of aqueous extracts of leaf, root, and stem of E. hypericifolia. The activities of phenolic compounds in impeding crucial biosynthetic functions (including, photosynthesis, respiration, and enzymatic activities), and interfering with processes of energy metabolism, cell division, and mineral uptake, has been well documented [81] [77]. The presence of phenolics in the leaf extracts of E. hypericifolia could thus have significantly advanced the suppression of germination, growth and biomass production in this study's targeted plants. This result validates previous findings by Ndam et al. [82] in investigation on the different phytochemical components of organic constituents in tissue and organ from 20 Donor medicinal plants found in Cameroon. The absence of saponins in the root material of E. hypericifolia during this study corroborates it the above research work. To date, findings have been presented on the inhibitory functions of specific phytochemicals, such as, $\mathrm{p}-$ coumaric and ferulic acids, which are derivatives of phenolic, and sesquiterpene lactones, as well as volatile constituents of essential oils from the Euphorbiaceae and Asteraceae families in particular [83]. P-coumaric, alkaloids, flavonoids, and phenolic acids have been shown to greatly impair plants utilization of water and expansion of leaf area, while ferulic acids is reported to negatively impacts lignification in soybean root [84]. The higher precipitation of secondary metabolites observed in the acetone extract could be allotted to it been reported to extract both polar and nonpolar compounds [85]. The fact that the extracts of E. bypericifolia contain allelochemicals may be a partial justification of the allelopathic attributes of the plant and the reason behind its invasivebility.

\section{Conclusions}

The findings of this study has established that E. hypericifolia is allelopathic, probably its mechanism of invasion with its leaf being very potent. In a concentration-dependent pattern, the aqueous extract, rhizophoric soil and soil- incorporated dry leaf residue of E. hypericifolia also, demonstrated stimulatory and phytotoxic effects on germination, morphometric and physiological traits of targeted plants in the sensitivity order of tomato $>$ black jack $>$ lettuce $>$ spiny amaranth $>$ maize. The plant is rich in secondary metabolites including alkaloids, glycosides, flavonoids, phenolics, tanins, steriods and saponins in varied quantities, with acetone being the best extractant amongst the solvents used. These compounds are therefore responsible for the allelopathic activities of the plant. This is the first report that highlights the significance of $E$. bypericifolia as a source of possible bioherbicides and plant growth promoting substances. Given the need for understanding the ravages of invasive alien species on the environment and employing its mechanism of perpetuation in sustainable agriculture especially in weed control, the findings of this work, sets a baseline for exploitation in crop production and protection. Notwithstanding the achievements of this study, need arises for future investigations into how the population genetics of E. hypericifolia varies in native ranges compared to introduced ranges. Additionally, such analysis could serve for better understanding of the evolution of invasive plants, and also provide information for management of plant invasions in both managed and natural ecosystems.

\section{Declarations}

\subsection{Acknowledgements}

This study was financially supported by Community Career Development Foundation Cameroon (COCADEF GRANT No.1018). The authors thank the Department of chemistry of the University of Buea, Cameroon for assistance in chemical analysis and Tokyo University of Agriculture and Technology, Japan for training on allelopathic bioassay techniques and provision of basic assay equipment. 


\subsection{Competing Interests}

The authors declare that they have no competing interests.

\section{How to Cite this Article:}

L. M. Ndam, A. M. Ngone, R. N. Nkongho, A. G. N. Fongod, and Y. Fujii, "Allelopathic Potentiality of Euphorbia hypericifolia L. on Germination and Seedling Development of Sympatric Crops and Weeds", Int. Ann. Sci., vol. 10, no. 1, pp. 134-150, Apr. 2021. doi: https://doi.org/10.21467/ias.10.1.134-150

\section{References}

[1] A. Shekoofa, S. Safikhan, T.B. Raper, and S. A. Butler, "Allelopathic Impacts of Cover Crop Species and Termination Timing on Cotton Germination and Seedling Growth" Journal $f$ Agronomy vol.10, no.1: pp.638-647. https://doi.org/10.3390/agronomy10050638

[2] A post-2020 target on invasive alien species (IAS), "An IUCN \& IUCN SSC Invasive Species Specialist Group proposal for a global target to address IAS, which is made without prejudice to IUCNs final position on the post-2020 framework. https://imo.org

[3] D. Moodley, L. Foxcroft, A. Novoa, K. Pyšková, J. Perg, and P. Pyšek, "Invasive alien species add to the uncertain future of protected areas" NeoBiota vol. 57: pp. 1-5, May 18,2020. https://doi.org/10.3897/neobiota.57.52188

[4] J. M.Waititu, C. N. Mundia1, and A.W. Sichangi, "Assessing distribution changes of selected native and alien invasive plant species under changing climatic conditions in Nyeri County, Kenya" AUGUST 25, 2020 :

https://doi.org/10.1101/2020.08.25.265991.

[5] E.M.Lind, J.D. Parker, "Novel Weapon testing: Are invasive plants more chemically defended than native plants? Plo one vol. 5, no. 5, pp. 1-3, May 3, 2010, https://doi.org/10.1371/journal.pone.0010429

[6] G. Y. Ni, P. Zhao, Q. Q. Huang, Y. P. Hou, C. M. Zhou, Q. P. Cao, and S. L. Peng, "Exploring the Novel Weapons Hypothesis with invasive plant species in China" Allelopathy Journal vol. 29, No. 2. pp. 199-214, Feb 6, 2012.

[7] F. Cheng, and Z. Cheng, "Research Progress on the use of Plant Allelopathy in Agriculture and the Physiological and Ecological Mechanisms of Allelopathy" Front. Plant Sci. 6:1020, pp.1-16, November 4, 2015. https://doi.org/10.3389/fpls.2015.01020

[8] R.M.Callaway, and W.M. Ridenour, "Novel Weapons: Invasive Success and the Evolution of Increased Competitive Ability". Frontier Ecological Environment vol. 2: pp.436-443., April, 2004

[9] H. Shi, S. Sun, X. Liu, J. Fan, J. Wang, K. Zhao, and W. Wang, “Allelopathic Potential and Mechanism of Rosebay Willow herb [Chamaenerion angustifolium (L.) Scop.] Demonstrated on Model Plant Lettuce" Phyton -International Journal of Experimental Botany vol. 89:Pp.45-123, June 11, 2020, https://doi.org/10.32604/phyton.2020.011620

[10] N. Novak, M.Novaki, K. Barić, M. Šćepanović, And D. Ivić, "Allelopathic potential of segetal and ruderal invasive alien plants" Journal of Central European Agriculture, 2018, 19(2), pp.408-422, Feb,2018.https://doi.org/10.5513/JCEA01/19.2.2116

[11] L. Kural, and R.Y. Özkan, "Allelopathic potential of white cabbage on some plants" Plant, Soil and Environment vol. 66:pp.559563 Nov, 2020. https://doi.org/10.17221/386/2020-PSE

[12] A. Mehmood, A. Tanveer, M.A. Nadeem., and Z.A. Zahir, "Comparative allelopathic potential of metabolites of two Alternanthera species against germination and seedling growth of rice" Planta Daninha vol. 32, no.1:Pp.1-10, Feb 2. 2014.

[13] H. Kato-Noguchi, "Involvement of Allelopathy in the Invasive Potential of Tithonia diversifolia" Plants vol. 9: pp.766, June 19, 2020. https://doi.org/10.3390/plants9060766

[14] A. Qayyum, M.K. Rafiq, K. Zahara, Y..Bibi, A.Sher, M.T. Rafiq, R. Aziz, and A. Manaf, “Allelopathic Effects Of Invasive Prosopis Juliflora On Grass Species Of Potohar Plateau, Pakistan” Planta Daninha vol.36: pp. 018-18250, Sept 13, 2018. https://doi.org/10.1590/S0100-83582018360100123

[15] B. Chen, H. Liao, W. Chen, H. Wei and S. Peng, "Role of allelopathy in plant invasion and control of invasive plants" Allelopathy Journal vol. 41 no. 2: pp. 155-166, July, 2017.

[16] M. Milanovića, S. Knappa, P. Pyšekc, and I. Kühna, "Linking traits of invasive plants with ecosystem services and disservices" Ecosystem Services vol. 42:pp.101072. Jan 21, 2020. https://doi.org/10.1016/j.ecoser.2020.101072

[17] P. K. Raia, and J.S. Singhb, "Invasive alien plant species: Their impact on environment, ecosystem services and human health" Ecological Indicators vol. 111: pp.106020, Jan 9, 2020. https://doi.org/10.1016/j.ecolind.2019.106020

[18] P. Kanatas, "Potential role of Eucalyptus spp. and Acacia spp. allelochemicals in weed management" Chilean Journal of Agricultural Research 80(3) May 28, 2020. May 2020. https://doi.org/104067/S0718-58392020000300452

[19] R.Dukpa, A. Tiwari, and D. Kapoor, "Biological management of allelopathic plant Parthenium sp." Open Agriculture vol. 5: pp.252-26,2020 https://doi.org/10.1515/opag-20200027

[20] R.J.Willis, "The historical bases of the concept of allelopathy" Journal of the History of Biology vol. 18, pp.71-102, March, 1985. https://doi.org/10.1007/BF00127958

[21] Senguttuvan, S. Paulsamy, and K. Karthika, "Phytochemical analysis and evaluation of leaf and root parts of the medicinal herb, Hypochaeris radicata L. for in vitro antioxidant activities" Asian Pacific Journal of Tropical Biomedicine Vol. 1: pp.359-367, April 2, 2014. https://doi.org/10.12980/APJTB.4.2014C1030

[22] M. I. Hussain, M.A. El-Sheikh, and M.J. Reigosa, "Allelopathic Potential of Aqueous Extract from Acacia melanoxylon R. Br. on Lactuca sativa. Journal of Plants vol. 9:pp. 1228. July 24, 2019. https://doi.org/10.3390/plants9091228

[23] S.S. Narwal, "Allelopathy in Weed Management” Allelopathy Journal vol. 2, pp.203-254, January, 1999

[24] H. Ohigashi, M. Kaji, J. Hoshino, J. Jato. and Koshimizu, K.Koshimizu, "The Search for Useful Plants in the Tropical Rain Forest of Cameroon and the Biological Activities of these Plants. Africa-Kenkyu" Journal of African Studies vol.30: pp.1-14, 1987

[25] P. Lorenzo, M Hussain, and L. González, "Role of Allelopathy During Invasion Process by Alien Invasive Plants in Terrestrial Ecosystems" Journal of Allelopathy Oct 17, 2014,. https://doi.org/10.1007/978-3-642-30595-5_1 
[26] W. Chengxu, Z. Mingxing, C, Xuhui, and Q. Bo, "Review on allelopathy of exotic invasive plants" Procedia Eng vol.18:pp.240246. 2011.

[27] J. M. Onana, "The Vascular Plants of Cameroon: A Taxonomic Checklist with IUCN Assessment”. In: Onana J.-M. (Eds.) Flore du Cameroun occasional. Yaoundé, IRAD-National Herbarium of Cameroon. vol. 39, no: pp.1-195, 2011

[28] Y. Harvey, B. Tchieuque, and M. Cheek, "The Plants of Lebialem Highland, Cameroon" A Conservation Checklist. Royal Botanic Garden, Kew, UK, pp.7-31. 2010

[29] F. A. Toh, T. E. Angwafo, L. Ndam and A. Mvondo Ze,_"The Socio-Economic Impact of Land Use and Land Cover Change on the Inhabitants of Mount Bambouto Caldera of the Western Highlands of Cameroon” , Advances in Remote Sensing vol.7, no.1:pp.25-45, January 2018

[30] D. Nafan, B.N.Divine, K. César, K.Christophe, and S. Abdourahamane "Phenotypic Diversity of Shea (Vitellaria Paradoxa C. F. Gaertn.) Populations across Four Agro-Ecological Zones of Cameroon” Journal of Crop Science and Biotechnology vol.10, no. 4: pp.211- 218, 2008

[31] Y. Harvey, B. Tchieuque, and M. Cheek, “The Plants of Lebialem Highland, Cameroon," A Conservation Checklist” Royal Botanic Garden, Kew, UK, pp.7-31, 2010.

[32] MINAGRIRD, "Final Project Report on Weed diversity in subsistent farming systems in SouthWestern Cameroon" Pp. 105, 2014

[33] S. Sciandrello, P. Minissale, and G. Guisso de Galdo, "Euphorbia hypericifolia L. (Euphorbiaceae, a new Alien Species for Italy" Journal of Plant Science and Geography vol.5, no.6:pp.214-237, March 24, 2016, https://doi10.1080/00837792.2016.1152669

[34] CABI "Fallopia japonica [Original text by AN Author] In: Invasive Species Compendium. Wallingford, UK: CAB International" compendia interactive encyclopedias, 2021, www.cabi.org/isc

[35] A. Rivera-Mondragón, S. Bijttebier, E. Tuenter, D. Custers1, O. ortíz, L. Pieters, C. Caballero-George, S. Apers and K. Foubert, "Phytochemical characterization and comparative studies of four Cecropia species collected in panama using multivariate data analysis" Scientific reports vol. 9: pp. 1763, Feb11,2019. https://doi.org/10.1038/s41598-018-38334-4

[36] I. Rezendes, E. R. Baseggio, L. Galon, D. Brandler, C. T. Forte, I. Aspiazú, M. B. Franceschetti, and A. Ferreira, "Allelopathy of weeds on the growth of vegetables"Journal of Plant Sciences vol. 10: Pp. 8-20, April 1, 2020.

[37] A. H. Al-shatti, A. Redha, P. Suleman and R. Al-Hasan "The Allelopathic potential of Conocarpus lancifolius (Engl.) leaves on Dicot (Vignia sinensis L.) Monocot (Zea mays L.) and Soil-Borne Pathogenic Fungi” American Journal of plant Sciences vol.5, pp. 2889-2903, 2014

[38] A. Mungole, S. Day, R. Kamble, H. Kanfade, A. Chaturvedi, and P. Zanwar, "Active Phytochemical and Antibacterial Potentiality of In-vitro Regenerated Plantlets of Canscora decurrens (Dalzell)" Indian Journal of Science and Technology 6: 679-683, 2010

[39] Y. Fujii, S.S. Parvez, M.M. Parvez, Y. Ohmae, and O. Iida, "Screening of 239 Medicinal Plant Species for Allelopathic Activity Using Sandwich Method" Weed Biology and Management 3: 233-241, 2003

[40] B. Bezeng, K. Yessoufou, P. Taylor, and S. Tesfamichae, "Expected spatial patterns of alien woody plants in South Africa's protected areas under current scenario of climate change" Scientific reports vol. 10: pp.7038., 2005 https://doi.org/10.1038/s41598020-63830-x

[41] P. Piyatida, K. Suenaga, and H. Kato-Noguchi, "Allelopathic Potential and Chemical Composition of Rhinacanthus nasutus Extracts" Allelopathy Journal vol. 26, no.2: 207-216, 2010

[42] 68 D.I. Arnon, "Copper enzyme polyphenoloxides in isolated chloroplast in Beta vulgaris" Plant Physiology. 24: 1-15, 1949

[43] J. Kamal, “ALLELOPATHY; A BRIEF REVIEW” Journal of Novel Applied Sciences Available online at www.jnasci.org @2020 JNAS Journal-2020-9-1/1-12

[44] H.F. Harrison, D.M. Jackson, A.P. Keinath, P.C. Marino, and T. Pullaro, "Broccoli production in cowpea, soybean, and velvet bean cover crop mulches. HortTechnology 14:484-487, 2004

[45] J. Kamal, "Impact of allelopathy of sunflower (Helianthus annuus L.) roots extract on physiology of wheat (Triticum aestivum L.)" Afr. J. biotechnol, vol.10, no.65: pp. 14465-14477, 2011

[46] M. A. Turk, K.D. Lee and A. M. Tawaha, "Inhibitory effects of aqueous extracts of Black mustard on germination and growth of radish" Research Journal of Agriculture and Bilogical sciences 1(3):pp. 227-231, Jan 9, 2005.

[47] Inderjit, and K.M.M. Dakshini, "Quercetin and Quercetrin from Luchea lanceolata and their Effects on Growth of Asparagus bean. In: Inderjit, Dakshini, K.M.M. and Einhellig, F.A. (Eds.). Allelopathy: Organisms, Processes and Application” American Chemical Society vol. 582:pp. 86-95, Dec 9, 1995, https://doi.org/10.1021/bk-1995-0582.ch006

[48] H.l. Semenchenko, A.V. Melnyk, V.F. Zavertalyuk, A.V. Zavertalyuk, V.I. Pastukhov, and R.V. Kyrychenko, "The effectiveness of compatible agrophytocenoses depending on the allelopathic interaction of plants" Ukrainian Journal of Ecology vol. 10, No. 4: pp.54-59, August 25, 2020. https://doi.org/10.15421/2020_167

[49] J.R. Teasdale, "Cover crops, smother plants, and weed management. In: J.L. Hatfield, D.D. Buhler, and B.A. Stewart (eds.).Integrated weed and soil management. Ann Arbor" Press, Chelsea, Mich. p. 247-270, 1998

[50] G. Thiébaut, M. Tarayre, and H. Rodríguez-Pérez, "Allelopathic Effects of Native Versus Invasive Plants on One Major Invader"Frontiers in Plant Science vol. 10:pp. 854, July 2, 2019. https://doi.org/10.3389/fpls.2019.00854

[51] T. Bareke, "Biology of seed development and germination physiology" Adv plants Agric Res vol. 8, no. 4: pp336-346, August 8, 2018. https://doi.org/10.15406/apar.2018.08.00335

[52] C. Eduardo de Souza Nascimento, C. Domingues da Silva, I. Leal, Wagner de Souza Tavares, J. Eduardo Serrão, J. C. Zanuncio, and M. Tabarell, "Seed germination and early seedling survival of the invasive species Prosopis juliflora (Fabaceae) depend on habitat and seed dispersal mode in the Caatinga dry forest" PeerJ, vol.8:pp.9607, Sept 3,2020. https://doi.org/10.7717/peerj.9607

[53] H. Cheng, S. Wang, M. Wei, Y. Yu, and C. Wang, "Effect of leaf water extracts of four Asteraceae alien invasive plants on germination performance of Lactuca sativa L. under acid deposition” Research square vol.1: pp.1-13, March, 2012, https://doi.org/10.21203/rs.3.rs-171195/v1

[54] J.A. Caamal-Maldonado, J. J. Jimenez-Osornio, A. Torres-Barragan, and A.L. Anaya. "The use of allelopathic legume cover crops and mulch species for weed control in cropping systems" Agron. J. vol.93:27-36, 2001. https://doi.org/10.3167/ares.2001.0401044 
[55] M. Scognamiglio, B. D’Abrosca, and A. Fiorentino, "Plant growth inhibitors: Allelopathic role or phytotoxic effects" Photochemistry reviews vol. 12: pp.803-830, March 19, 2013, https://doi.org/10.1007/s11101-013-9281-9

[56] Y. Fujii, T. Shibuya, and T.Yasuda "Survey of Japanese Weed and Crops, for the Detection of Water-extractable Allelopathic Chemicals using Richards' Function Fitted to Lettuce Germination Test” Weed Resource. Japan 35: 362-370, 1990

[57] E.C. Hill, M. Ngouajio, and M.G. Nair, "Differential response of weeds and vegetablecrops to aqueous extracts of hairy vetch and cowpea. HortScience 41:695-700, 2006

[58] S. Bhattacharya, S. Namasudra, S. Debnath, and A. Saha, "Comparative Allelopathic Effects of Two Weed Extracts on Seed Germination and Seedling Growth of Vigna unguiculata (L.) Walp and Abelmoschus esculentus L." Defence Life Science Journal, vol. 5, No: pp. 204-210, July 2020. https://doi.org/10.14429/dlsj.5.15653

[59] C. Fortwangler, "Untangling Introduced and Invasive Animals" Environment and Society: Advances in Research No 4: 41-59, April, 2013. https://doi.org/10.3167/ares.2013.040104

[60] J. J. Meyer, C. E. Schutte, J. W. Hurter, N. S. Galt, P. Degashu, G. Breetzke, D. Baranenko, and N. L. Meyer, “The allelopathic, adhesive, hydrophobic and toxic latex of Euphorbia species is the cause of fairy circles investigated at several locations in Namibia" BMC Ecology vol. 20:pp.45. 2020. https://doi.org/10.1186/s12898-020-00313-7

[61] K..Lapin, J.Oettel, H. Steiner, M. Langmaier, D. Sustic, F. Starlinger, G. Kindermann, and G. Frank, "Invasive alien plant species in unmanaged forest reserves, Austria" NeoBiota vol. 48: pp.71-96, July 15, 2019. https://doi.org/10.3897/neobiota.48.3474

[62] Y.Yuan, B. Wang, S. Zhang, J. Tang, C. Tu, S. Hu, W. Jean, H. Yong, and X. Chen, "Enhanced allelopathy and competitive ability of invasive plant Solidago canadensis in its introduced range" Vol. 6 No. 3:pp. 253-263, June 2013. https://doi.org/10.1093/jpe/rts033

[63] J. kamal, "Jordan Journal of Applied Science” Journal of Novel Applied Sciences vol. 9, no. 1:Pp. 1-12, January 2020.

[64] S. E. Ahmed, N. K. Messiha, R. R. El-Masry, and M. A. El-Dabaa, "The dual allelopathic capacity of two Brassicaceae plants' seed powder in controlling Orobanche crenata infesting Pisum sativum as well as stimulating its growth and yield" National Research Centre vol.44, no. 17:pp.2-8, March 2020. https://doi.org/10.1186/s42269-020-0276-6

[65] S.K. Maity, and A.K. Samanta, "Allelopathic influence of Eupatorium odoratum L. on germination and seedling growth of some pulses" International Research Journal of Basic and Applied Sciences vol.5.Nov 8, 2020 RNI : WBENG/2016/76189

[66] S. Abugre, and S.J.Quashie-Sam, "Evaluating the Allelopathic effect of Jatropha curcas aqueous extract on germination, radicle and plumule length of crops" International Journal of Agriculture and Biolog vol.12 no. 5: pp. 769-772, 2010,

[67] F.A. Einhellig, J.A.Rasmussen, A.M. Hejl, and I.F. Souza, "Effects of Root Exudate Sorgoleone on Photosynthesis" Journal of Chemical Ecology vol. 19:pp. 369-375, 1993

[68] R. Vaishali, and C. Alka, "Allelopathic effect of some plants on morphological attributes of invasive alien weed: Malachra capitata (L.)L.”GSC Biological and Pharmaceutical Sciences vol. 6 no. 2:pp. 108-114, Feb 272019. https://doi.org/10.30574/gscbps.2019.6.2.0020

[69] M. J. Adler, and C. A. Chase, "Comparison of the Allelopathic Potential of Leguminous Summer Cover Crops: Cowpea, Sunn Hemp, and Velvet bean” Hortscience 42(2):289-293. 2007. Dec 03, 2006:

[70] M. Imatomi, P. Novaes, and S. C.Gualtieri, “Insterspecific variation in the allelopathic potential of the family Myrtaceae" Acta Botanica Brasilica vol.27 no.1: pp.54-61, Oct 10, 2013

[71] Fujii, Y., Shibuya, T. and Yasuda, T. (1990). Survey of Japanese Weed and Crops, for the Detection of Water-extractable Allelopathic Chemicals using Richards' Function Fitted to Lettuce Germination Test. Weed Resource. Japan vol. 35: $362-370$.

[72] M. Maver, B. Miras-Moreno, L. Lucini, M. Trevisan, Y. Pii, S. Cesco, and T. Mimmo, "New insights in the allelopathic traits of different barley genotypes: Middle Eastern and Tibetan wild-relative accessions vs. cultivated modern barley" Journal of pone vol. 15, No.4:pp.231-976. April 23, 2020. https://doi.org/10.1371/journal.pone.0231976

[73] F.A. Einhellig, "Allelopathy: Current status and future goals In: Allelopathy: Organisms, Processes and Applications. Edited by Inderjit, K. M. M. Dakishini and F. A. Einhellig, ACS Symposium Series” American Chemical Society vol.582: pp. 1-25, 1995

[74] J.D.Weidenhamer, D. C. Hartnett, and J.T. Romeo, "Density-dependent Phytotoxicity: Distinguishing Resource Competition and Allelopathic Interference in Plants. Journal of Applied Ecology vol. 26, no. 2: 613-624, August, 1989, https://doi.org/10.2307/2404086

[75] M. Granata, F. Bracco, and R. Catoni, "Phenotypic plasticity of two invasive alien plant species inside a deciduous forest in a strict nature reserve in Italy" Journal of Sustainable Forestry, vol. 39, no. 4:pp.346-364, Sept 30, 2019. https://doi.org/10.1080/10549811.2019.1670678

[76] E.J. Solteiro, J.A. Machado, and P.B. Oliveira, "An Evolutionary Approach to Robot Structure and Trajectory Optimization," ICAR'01-10th International Conference on Advanced Robotics, Budapest, pp. 333-338, 22-25 August 2001,

[77] S. Dallali, S. Rouz, H. Aichi, and H. Hassine, "Phenolic contentand allelopathic potential of leaves and rhizosphere soil aqueous extracts of white horehound (Maribum vulgare L.)" Journal of new sciences, Agriculture and Biotechnology vol. 39, no.3: pp. 2106-2120, March 1, 2017.

[78] O.O. Otusanya, O.J. Illori, and A.A. Adelusi "Allelopathic effect of Tithonia diversifolia (Hemsl) A. Gray on Germination and Growth of Amaranthus cruentus" Research Journal of Environmental Science vol. 1, no. 6: pp.285-293, 2007

[79] S.M. El-Darier, E.T. El-Kenany, E.E. Fawzy, "Assessment of contribution of allelospoly and allelopathy to interference of Medicago sativa with Raphanus sativus" Egypt. J. Exp. Biol. (Bot.) vol. 15, no. 2: $205-2152019$. https://doi.org/10.5455/egyjebb.20190628044001

[80] S. Krajšek, E. Bahčič, U.S. Čoko and J. D. Koce, "Disposal methods for selected invasive plant species used as ornamental garden plants" Management of Biological Invasions vol. 11, no. 2:pp. 293-305, Feb 28, 2020. https://doi.org/10.3391/mbi.2020.11.2.08 293-305

[81] R. Marchiosi, W. D. Santos and R.P. constantin, "Biosynthesis and metabolic actions of simple phenolic acids in plants" Phytochem Rev vol.19: pp. 865-906, May 29, 2020, https://doi.org/10.1007/s11101-020-09689-2 
Ndam et al., Int. Ann. Sci.; Vol. 10, Issue 1, pp: 134-150, 2021

[82] L.M. Ndam, A.M. Mih, A.G.N. Fongod, A.S. Tening, N.A. Temenu, J.E. Enang, and Y. Fujii, "Phytochemical Screening of the Bioactive Compounds in Twenty (20) Cameroonian Medicinal Plants" International Journal of Current Microbiology and Applied Sciences vol. 3, no. 12: 768-778, 2014

[83] L.M. Ndam, A.M. Mih, A.G.N. Fongod, A.S. Tening, R.K. Tonjock, and Y. Fujii, "Phytochemical analysis, antimicrobial and antioxidant activities of Euphorbia golondrina L.C. Wheeler (Euphorbiaceae Juss.): an unexplored medicinal herb reported from Cameroon" Springer Plus vol. 2, no. 5:264, 2016

[84] U. Blum, and T.M. Gerig, "Interrelationship Between p-coumaric Acid Evapotranspration, Soil Water Content and Leaf Expansion" Journal of Chemical Ecology vol. 32: 1817-1834, 2006

[85] J. N. Eloff, "Which extractant should be used for the screening and isolation of antimicrobial components from plants?" $J$ Ethnopharmacol vol. 60:pp.1-8, 1998

Publish your books with AIJR publisherPublish with ISBN and DOI. Publish Thesis/Dissertation as Monograph.

Publish Book Monograph.

Publish Edited Volume/ Book.

Publish Conference Proceedings

Retain full copyright of your books.

Submit your manuscript at books.aijr.org
Publish your research article in AIJR journals-

$\checkmark$ Online Submission and Tracking

$\checkmark$ Peer-Reviewed

$\checkmark \quad$ Rapid decision

$\checkmark \quad$ Immediate Publication after acceptance

$\checkmark \quad$ Articles freely available online

Retain full copyright of your article.

Submit your article at journals.aijr.org 